\title{
Training to Rescue and Repair Data on Flashdisk Storage for Elementary School Teachers of Pal Merah 19, West Jakarta
}

\section{Pelatihan Penyelamatan Dan Perbaikan Data Pada Penyimpanan Flashdisk Untuk Guru Sekolah Dasar 19 Pal Merah, Jakarta Barat}

\author{
Dewi Anjani*, Desi Novianti, Retna Ningsih \\ Informatika, Universitas Indraprasta PGRI, Indonesia
}

\begin{abstract}
Educators at Elementary School of Pal Merah 19, West Jakarta have used computer technology to access information, both for teaching and personal needs. The information obtained is usually stored by means of flash storage media. Flash data storage media is a tool used to store data or programs where the stored data can be read back to be processed by a computer. However, this medium is prone to the data loss, and the limitations of educators regarding to the data recovery and data recovery information require the teachers to have one or more flashdisk to solve this problem. To overcome this problem, community service activities were held which introduced and provided Training on Data Rescue and Repair on Flashdisk Storage to Elementary School Teachers of Palmerah 19, West Jakarta, so that they could store and repair the data on flashdisk independently, by using the software knowns as Recuva.
\end{abstract}

\begin{abstract}
Abstrak
Pendidik pada Sekolah Dasar 19 Palmerah, Jakarta Barat telah memanfaatkan teknologi komputer untuk mengakses informasi, baik untuk kebutuhan mengajar ataupun kebutuhan pribadi. Informasi yang di perolah biasanya disimpan menggunakan media penyimpanan flashdisk. Media penyimpan data flashdisk adalah alat yang digunakan untuk menyimpan data atau program dimana data yang disimpan tersebut dapat dibaca kembali untuk diproses oleh komputer. Namun media ini rentan terhadap kehilangan data, dan keterbatasan pendidik tentang informasi penyelamatan data dan perbaikan data, membuat harus memiliki satu atau lebih falshdisk untuk mengatasi masalah ini. Untuk memecahkan masalah tersebut, maka diadakan sebuah kegiatan pengabdian kepada masyarakat yang memperkenalkan dan pemberian Pelatihan Penyelamatan dan Perbaikan Data pada Penyimpanan Flashdisk kepada para Guru Sekolah Dasar 19 Palmerah, Jakarta Barat, sehingga dapat melakukan penyimpanan dan perbaikan data pada flashdisk secara mandiri. Dimana software yang digunakan adalah Recuva.
\end{abstract}

(C) 2020 Author(s).

Keywords: Data storage, Data repair, Recuva.

\section{Pendahuluan}

Media penyimpan data adalah alat yang digunakan untuk menyimpan data atau program dimana data yang disimpan tersebut dapat dibaca kembali untuk diproses oleh komputer. Beberapa peralatan yang termasuk media penyimpan diantaranya adalah memori. Jenis media penyimpanan media penyimpan diantaranya: harddisk, compact disk (CD), USB, dan lain - lain.

\footnotetext{
* Corresponding author:

E-mail address: dewiunindra@gmail.com (Dewi Anjani)
} 
USB flash drive (Flashdisk atau UFD) adalah alat penyimpanan data memori flash tipe NAND yang memiliki alat penghubung USB yang terintegrasi (http://kaskusfans.com/news/sejarahflashdisk.php). Flash drive ini biasanya berukuran kecil, ringan, serta bisa dibaca dan ditulisi dengan mudah (http://id.wikipedia.org/wiki/USB_flash_drive). Memudahkan para pengguna tidak lagi dan memikul beban yang cukup besar, hal ini didasari perkembangan cukup pesat sejak adanya disket, CD hingga hardis (Nandiroh, 2007)

Namun flashdisk rentan dari berbagai ancaman seperti terhapus atau hilangnya data dikarenakan terserang oleh virus atau malware. Kehilangan data yang paling banyak terjadi umumnya adalah data di flashdisk yang tiba-tiba hilang, flashdisk yang minta diformat sehingga menyebabkan file hilang, dan lainnya (Simanjuntak, 2017). Analisa baik buruknya sistem tidak dapat dilihat dengan nyata tetapi harus dilakukan secara online dan offline. Media tampilan angka, tabel dan grafik kecepatan baca dan tulis tersimpan ketika perangkat terhubung ke sistem (Efendi, n.d.)

Sekolah Dasar 19 Palmerah, Jakarta Barat merupakan tempat pendidikan anak yang berusia antara 7 sampai dengan 13 tahun sebagai pendidikan di tingkat dasar yang dikembangkan sesuai dengan satuan pendidikan, potensi daerah/karakteristik daerah, sosial budaya masyarakat setempat bagi siswa. Sekolah Dasar, Pendidik telah memanfaatkan teknologi komputer untuk mengakses informasi, baik untuk kebutuhan mengajar ataupun kebutuhan pribadi (Kamblea, 2015).

Informasi yang didapat, disimpan dalam sebuah penyimpanan seperti flashdisk, sehingga permasalahan kehilangan data pada penggunaan media ini tidak dapat dihindari. Namun adanya keterbatasn pendidik dalam informasi tentang penyelamatan data dan perbaikan data, membuat harus memiliki satu atau lebih falshdisk untuk mengatasi masalah ini.

\section{Pelaksanaan dan Metode}

Pelaksanaannya bertempat di Sekolah Dasar 19, Palmerah, Jakarta Barat. Kegiatan dilaksanakan selama 1 (satu) bulan dengan masing-masing tatap muka 21/2 (dua setengah jam) dan 4 (empat) kali pertemuan diperuntukan bagi para guru Sekolah Dasar 19 Pal Merah, Jakarta Barat.

Metode pelaksanaannya adalah sebagai berikut:

1. Tatap muka pertama penjelasan tentang beberapa alat penyimpanan data, dan Software Recovery USB, mendemontrasikan menggunakan proyektor dilanjutkan dengan tanya jawab dan diskusi.

2. Tatap muka kedua mendemontrasikan dan langsung mempraktikan cara mengembalikan data di flashdisk yang tiba-tiba hilang dilanjutkan dengan praktek dan contoh.

3. Tatap muka ketiga mendemontrasikan dan langsung mempraktikan cara memperbaiki flashdisk yang minta diformat agar file tidak hilang

4. Tatap muka keempat mendemontrasikan dan langsung mempraktikan mengembalikan data di flashdisk yang telah format.

Partisipasi Mitra dalam pelaksanaan kegiatan ini yaitu dengan membantu menyediakan tempat pelatihan, peralatan seperti infokus, komputer dan mengkoordinasi antara peserta dan pemberi pelatihan.

\section{Hasil dan Pembahasan}

Pelaksanaan kegiatan ini dilakukan dengan online menggunakan aplikasi zoom. Dimana terdiri dari 14 guru dan 4 staf sekolah. Tatap muka pertama penjelasan tentang beberapa alat penyimpanan data, dan Software Recovery USB, penjelasan dibantu dengan menggunakan slide presentasi dilanjutkan dengan tanya jawab dan diskusi. Materi ini dijelaskan oleh ibu dewi, dimana dibagi menjadi 2 sesi yaitu tentang alat penyimpanan yang beredar di masyaratakat 
sekarang mulai dari flashdisk (USB) dengan ragam kapasitas penyimpanannya hingga hardisk eksternal. Hasil dari pertemuan ini, peserta dapat mengetahui alat penyimpanan yang tepat berdasarkan kondisi di lapangan.

Tatap muka kedua mendemontrasikan dan langsung mempraktikan cara mengembalikan data di flashdisk yang tibatiba hilang dilanjutkan dengan praktek dan contoh. Materi kedua ini disampaikn oleh ibu desi, dimana penjelasan dimulai dari beberapa penyebab flashdisk sering rusak seperti :

a. Port USB kotor-Salah satu hal yang sering terjadi adalah kerusakan yang dikarenakan Flashdisk kotor dan tidak dapat terdeteksi di Laptop biasanya hal ini dikarenakan USB kemasukan debu atau kotoran yang berada di USB tersebut.

b. Flashdisk Jarang di Eject - Flashdisk menjadi alat penyimpanan yang mempunyai tata caranya untuk dikeluarkan dan dimasukkan kedalam port USB komputer dan laptop. Setiap kali anda mencolokkan flashdisk diutamakan ketika selesai melakukan pemindahan atau menyalin data maka aturan untuk mengeluarkannya adalah dieject melalui klik kanan dan eject flashdisk.Tapi terkadang hal yang sering dilakukan adalah melepas langsung dari port USB komputer tersebut. Ini jika dilakukan terus menurus yang mengakibatkan flashdisk tidak terbaca lagi oleh komputer/laptop.

c. Flashdisk terkena virus - Adanya virus pada flashdisk ini menyebabkan file tidak dapat dibaca meskipun laptop dapat mendeteksi. Terkadang flashdisk yang suka terhubung dengan beberapa laptop rawan terkena virus, hal ini juga dapat disebabkan karena proses eject yang tidak tepat ketika flashdisk yang dikeluarkan dari perangkat.

Hasil dari pertemuan kedua adalah peserta dapat mengetahui penyebab flashdisk rusak, sehingga dengan mengetahui penyebabnya dapat lebih cepat untuk mencari solusinya. Tatap muka ketiga mendemontrasikan dan langsung mempraktikan cara memperbaiki flashdisk yang minta diformat agar file tidak hilang. Materi disampaikan oleh ibu dewi, namun dalam mempraktikan dengan cara memperbaiki flashdisk menggunakan video dan di share kepada peserta karena pertemuan bersifat online. Dalam kasus pertemuuan 3 ini, dimana data tidak perlu diselamatkan, sehingga flashdisk langsung saja di format dan Kembali seperti semula. Hasil petemuan ini, peserta mengetahui bahwa flashdisk yang minta di format bukan berarti rusak, ada beberapa penyebab seperti yang telah dijelaskan diatas. Sehingga tidak pelu panik dalam menghadapi kasus seperti ini di kemudian hari.

Tatap muka keempat mendemontrasikan dan langsung mempraktikan mengembalikan data di flashdisk yang telah format. Pada pertemuan ini di pandu oleh ibu desi, dimana pendekatan sama dengan pertemuan ketiga, dalam mempraktikan kasus menggunakan video dan ditambah dipandu langsung dengan share desktop pada zoom. Pada tujuan awal dari pengabdian ini adalah pengembalian data yang telah terformat, untuk mengmbalikan data menggunakan software recuva. Dimana software ini nantinya membantu mempermudah dalam pengembalian data.

Pada penjelasan awal, peserta dipandu untuk mendownload software recuva dan menginstallaikannya. Proses ini berlangsung sekitar 15-30 menit, sehingga para peserta sudah memiliki software dan sudah terinstall di laptop masing-masing. Kemudian peserta dibimbing untuk memformat flashdisk yang dikembalikan datanya, proses ini berlangsung 10-15 menit. Setelah semua peserta berhasil memformat flashdisk, maka dipandu untuk menggunakan recuva. Seperti langkah berikut:

a. Buka Recuva Wizard dari komputer, lalu pilih jenis file yang ingin Anda kembalikan, entah itu dalam bentuk gambar, musik, dokumen, video, atau jenis file lainnya. Kemudian, klik tombol "Next"

b. Sekarang tentukan lokasi penyimpanan file yang terhapus untuk mempercepat proses pencarian file yang hilang

c. Jika Anda merasa yakin bahwa file yang terhapus memang disimpan di lokasi yang sudah ditentukan, maka Anda bisa langsung klik "Next". Namun, bila Anda lupa atau tidak yakin mengenai lokasi penyimpanan file sebelum dihapus, pilih "I'm Not Sure" agar recuva yang menyortir file di seluruh lokasi komputer meskipun akan membutuhkan waktu yang cukup lama

d. Untuk memulai proses pencarian, centang kotak "Enable Deep Scan", lalu klik "Start" maka aplikasi ini akan melakukan pencarian dengan lebih teliti dan tentunya akan memakan waktu yang lebih lama 
e. Tunggu selama beberapa saat karena pencarian file sedang dilakukan dan dibagi menjadi 3 bagian, yakni mencari file yang terhapus, menganalisa kerusakan file, dan menganalisi isi file

f. Pilih file yang ingin dikembalikan dengan cara mencentang kotak di file-file yang ingin dikembalikan (gambar 3), lalu klik kanan dan pilih "Recover Highlited", akhiri dengan klik tombol "Recover" .

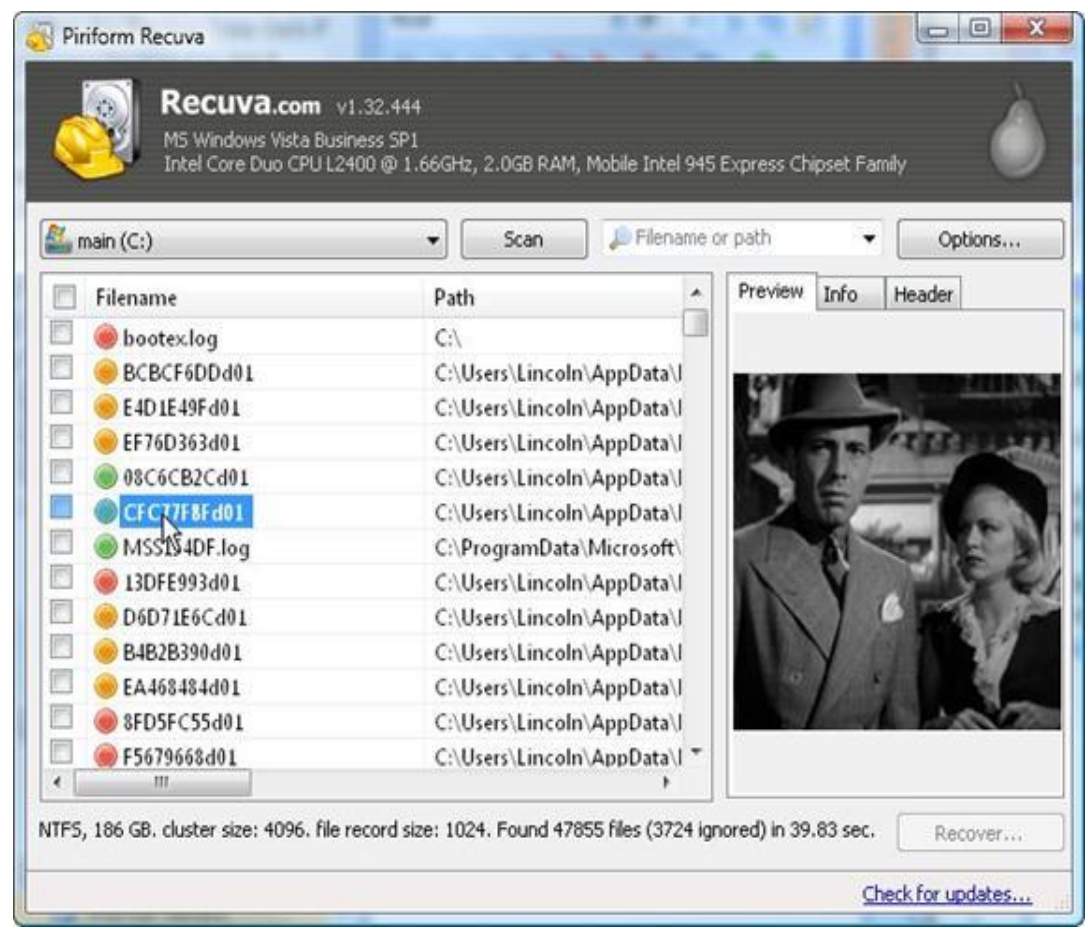

Fig. 1 File yang talah dideteksi dan dapat di pulihkan

Proses pengembalian file ini berlangsung 60-90 menit, dimana peserta kesulitan dalam mempraktikan setiap tahap, sehingga waktu dihabiskan menunggu peserta yang belum berhasil menyelesaikan per tahap. Hasil dari pertemuan ini, peseta sudah dapat mengembalikan file yang telah di format.

\section{Kesimpulan dan Saran}

\subsection{Kesimpulan}

Sekolah Dasar 19, Pendidik telah memanfaatkan teknologi komputer untuk mengakses informasi, baik untuk kebutuhan mengajar ataupun kebutuhan pribadi. Informasi yang didapat, disimpan dalam sebuah penyimpanan seperti flashdisk, sehingga permasalahan kehilangan data pada penggunaan media ini tidak dapat dihindari. Namun adanya keterbatasn pendidik dalam informasi tentang penyelamatan data dan perbaikan data, membuat harus memiliki satu atau lebih falshdisk untuk mengatasi masalah ini maka dibutuhkan pemberian pengetahuan tentang pemulihan data, sehingga tidak terjadi kepanikan pada saat flashdisk error.

Pemberian pengetahuan dilakuan dengan pendekatan pelatihan yang diadakan secara online menggunakan aplikasi zoom dengan 4 kali pertemuan. Dimana setiap pertemuan memberika peserta pengetahuan tentang jenis dan penyabab 
flashdisk error, dengan cara memformat flashdisk dan mengembalikan data pada flashdisk yang telah terformat dengan menggunakan aplikasi Recuva. Dengan demikian tujuan dari pelatihan ini dapat tercapai yaitu memberikan pengetahuan kepada para guru bagaimana mengembalikan data pada flashdisk.

\subsection{Saran}

Meskipun penggunaan aplikasi dapat dengan mudah mengambalikan data yang telah hilang, namun aplikasi tersbut apabila masih menggunakan versi gratis tidak maksimal dalam mengembalikan data. Sehingga sebaiknya para guru diberikan pengetahuan cara yang berbeda dalam mengembalikan data seperti menggunakan perintah pada command prompt.

\section{References}

Admin. (February 03, 2010). Sejarah FlashDisk. KaskusFans. Retrieved October 16, 2019, from https://web.archive.org/web/20121024040224/http://kaskusfans.com/news/sejarah-flashdisk.php

Effendi, I. (n.d.). Cara Mengetahui Kecepatan USB / Flashdisk. IT-JOURNAL.com. Retrieved November 29, 2020, from https://www.it-jurnal.com/cara-mengetahui-kecepatan-usb-flashdisk/

Kamblea, D. R., Jainb, N., \& Deshpandec, S. (2015). Comparison of Digital Forensic tools used in DFAI system. History, 2(6).

Nandiroh, S., Fitriadi, R., \& Hikmawati, H. (2007). Pengembangan Kolaborasi Desain Casing Produk Flash Disk Berbasis Web Yang Mendukung Karakteristik Kolaborasi. Jurnal Ilmiah Teknik Industri, 6(1), 48-57.

Simanjuntak, P. (2017). Analisis Perbandingan Aplikasi Pandora Recovery dan Recuva Terhadap Pengembalian Data Windows. Journal Information System Development (ISD), 2(1).

Wikipedia. (2018, May 24). USB Flash Disk. Retrieved October 16, 2019, from http://id.wikipedia.org/wiki/USB_flash_drive 